\title{
SUBKULTUR PESANTREN DALAM KARYA-KARYA DJAMIL SUHERMAN (TELAAH ANTROPOLOGI SASTRA)
}

\author{
(The Pesantren Subculture on the Works of Djamil Suherman; an Anthropological \\ Literature Analysis)
}

\author{
M. Rosyid Husnul Waro'i \\ Kajian Sastra dan Budaya, FIB Universitas Airlangga \\ Jl. Dharmawangsa Dalam, Surabaya 60286 \\ mrosyidhw15@gmail.com
}

(Naskah diterima tanggal 10 Oktober 2019_-Direvisi tanggal 5 November 2019_-Disetujui tanggal 21 November 2019)

\begin{abstract}
Pesantren as one of the largest and oldest Islamic education institutions in Indonesia certainly has a set of values and norms adopted by the community and maintained from time to time. One that records and documents the culture of the pesantren is literature. This study discusses literary works where pesantren culture is written. Therefore, the anthropological theory of literature is used as an analytical tool to reveal how literature records the culture of pesantren. The object of this research material is the work of Djamil Suherman; a collection of short stories of Umi Kalsum, Pejuang Kali Pepe novel, Sakerah novel and Sarip Tambak Oso novel. The data obtained in the form of words, sentences and phrases in the work are then processed and described using narrative descriptive forms. The results of the analysis show that the work of Djamil Suherman photographed the pesantren subculture in the form of traditional rituals, ethnographic or cultural elements and the way of life of the pesantren community.
\end{abstract}

Key Words: pesantren, subculture and anthropological literature

\section{PENDAHULUAN}

Pondok pesantren merupakan mutiara islam nusantara bagi Indonesia. Lembaga pendidikan islam ini telah mengakar kuat dan tersebar di pelbagai wilayah negeri ini. Membicarakan pendidikan bangsa ini, pesantren adalah salah satu lokomotif utamanya, jauh sebelum sekolah diintrodusir Belanda melalui kolonialisme.

Ki Hadjar Dewantara (1986) dalam Polemik Kebudayaan pada dekade 1930an menyatakan bahwa pondok pesantren adalah sebagai pusat pembangunan budi pekerti. Sementara Soetomo (1986) berpikir bahwa pesantren memberikan pengajaran lahir dan batin bagi murid-muridnya. Ia juga berpendapat bahwa pesantren berperan dalam menanamkan cinta tanah air dan spirit kebangsaan. Ini membuktikan bahwa para pemikir awal bangsa ini tidak menafikan peran dan kontribusi pesantren terhadap kemajuan peradaban Indonesia.

Kini, berdasarkan data pondok pesantren tahun 2018 yang dikelola Kementrian Agama, terdapat 25.938 pesantren dengan jumlah santri 3.962.700 di seluruh Indonesia. Jumlah itu hanyalah data yang tercatat secara resmi, masih banyak lagi pesantren-pesantren kecil dan terkadang tidak memiliki kelengkapan administrasi versi pemerintah hingga belum masuk dalam pangkalan data tersebut. Pesantren adalah salah satu lembaga pendidikan tertua yang telah dan akan terus menggerakkan roda pendidikan dan tranmisi pengetahuan di negara ini. 
Adalah Abdurrahman Wahid (1973), seorang putra pesantren, yang mula-mula mencatat tentang pesantren sebagai subkultur dalam sebuah esai panjangnya. Kategori sub-kebudayaan ini berdasarkan tiga aspek; cara hidup yang dianut, pandangan hidup dan tata nilai yang diikuti serta hierarki kekuasaan intern tersendiri. Ketiga aspek di atas di kalangan pesantren memiliki kekhasan tersendiri yang unik dan berbeda dengan lingkup dan komunitas sosial masyarakat yang lain di luar pesantren. Gus Dur juga menyakini bahwa identitas subkultur pesantren akan terus diuji seturut perubahan kultural di masyarakat. Ada semat harapan Gus Dur bahwa tata nilai pesantren tetap bertahan dan tidak hilang di tengah arus zaman.

Salah satu bidang keilmuan yang juga mendokumentasikan kultur pesantren dan seringkali jarang diperbincangkan adalah sastra. Karya sastra memiliki kekuatan yang tidak dimiliki oleh bidang lainnya yaitu mencatat detail-detail peristiwa kebudayaan melalui narasi, deskripsi dan refleksi beserta gejolak dan getar psikologis-sosiologisantropologis yang dirasakan oleh manusia. Berbeda dengan teks-teks lainnya, sastra juga mampu merekam nilai-nilai budaya sebagai dokumen sosial yang hidup melalui simbol dan tanda.

Salah satu pengarang sastra yang banyak menuliskan kultur pesantren dalam karya sastra adalah Djamil Suherman. Melalui novel-novelnya seperti PejuangPejuang Kali Pepe (1984), Sakerah (1985), Sarip Tambak Oso (1985), dan terutama kumpulan cerpennya Umi Kalsum (1984), Djamil bercerita tentang subkultur pesantren pada zaman kolonial, mulai dari peran kiai, pola pendidikan santri, kegiatan dan ritual keagamaan di pesantren hingga kisah perlawanan pesantren terhadap kolonialisme Belanda.

Nama Djamil Suherman dalam kancah sastra Indonesia sangat menarik ditinjau dari kaitan sastra dan kultur pesantren pada era sekarang ini setidaknya dari dua alasan. Pertama, karya-karya Djamil Suherman banyal menuliskan catatan antropologis tentang gambaran kebudayaan pesantren di zaman kolonial. Mengingat geliat perubahan pesantren di zaman sekarang yang berjalan terus menerus serta upaya modernisasi dan internasionalisasi pesantren dalam merespon perubahan masyarakat akibat revolusi teknologi, maka menelisik kembali sejarah dan budaya pesantren pada masa lampau adalah sebuah kebutuhan untuk menjaga tata nilai pesantren tetap pada rel kebudayaannya.

Pesantren secara historis memiliki sikap adaptif yang luar biasa terhadap perubahan zaman yang dibuktikan dengan keberadaannya hingga kini. Bahkan, pesantren mengalami perkembangan dan kemajuan yang luar biasa. Namun, bukan berarti segala perkembangan dan kemajuan itu meninggalkan tradisi dan budaya lama. Oleh karena itu, perlu peninjauan kembali terhadap budaya masa lampau yang hidup dan berlangsung di pesantren.

Maka, Djamil Suherman dan karya sastranya adalah salah satu pintu untuk menengok kembali catatan antropologis tentang subkultur pesantren melalui jalur sastra. Seperti harapan Gus Dur, bahwa agar pesantren tidak kehilangan tata nilainya meskipun masyarakat di sekelilingnya berubah. Seperti adagium yang menjadi panutan kalangan pesantren; Almuhafadzoh 'alal Qodimil ash-sholih, wal ahdzu bil jadidil ashlah; menjaga hal-hal masa lalu yang baik dan mengambil hal-hal baru yang lebih baik.

Kedua, Djamil Suherman pada masanya adalah pembaharu dalam bidang sastra karena menggarap tema pesantren yang belum ditulis oleh sastrawan lainnya. Kritikus sastra H.B. Jassin (1961) memuji kumcer Umi Kalsum sebagai kisah yang menarik karena menceritakan lingkungan pesantren yang 'sedikit sekali mendapat perhatian dari para pengarang'. Jalaluddin Rakhmat (1984) juga mengakui bahwa Djamil Suherman sebagai penulis yang banyak mengungkapkan kehidupan pesantren dalam karya-karya sastranya dan 
melukiskan komunitas pesantren tradisional dengan cermat dan hidup.

Djamil Suherman menjadi titik tolak penting untuk meneropong geliat sastra pesantren. Karena ia adalah pemula dan penulis awal tentang deskripsi kehidupan dan kebudayaan pesantren dengan detail. Di sisi lain, perkembangan keilmuan tentang kajian multidisipliner dalam pengkajian sastra pada masa Djamil hidup belumlah masif dan meningkat seperti sekarang. Walhasil, pendekatan antropologi sastra sebagai kajian multidisipliner patut digunakan dalam menganalisis karya-karya Djamil Suherman untuk menguak segi-segi kultur antropologis pesantren.

Berdasarkan latar belakang di atas, maka pertanyaan yang dikemukakan dalam tulisan ini meliputi: 1) bagaimana ritual tradisi orang pesantren yang tergambar dalam karya-karya Djamil Suherman? 2) bagaimanakah aspek-aspek subkultur pesantren yang terpotret dalam karya-karya Djamil Suherman? Lebih lanjut akan dijelaskan teori antropologi sastra yang dipakai dalam analisis.

Manusia hidup tidak akan terlepas dari hasil kebudayaannya seperti tata nilai, habitus adat, alat dan teknologi kehidupan hingga gugusan pengetahuan. Maka, sikap manusia pasti didasarkan pada struktur nilai tertentu yang akhirnya membentuk budaya sebuah komunitas sosial. Koentjaraningrat (1974: 82) menunjukkan tujuh ciri kebudayaan yang dapat digunakan untuk mengidentifikasi ciri-ciri antropologis dari sebuah kelompok masyarakat, yaitu a) peralatan dan perlengkapan kehidupan manusia, b) mata pencaharian dan sistem ekonomi c) sistem kemasyarakatan d) bahasa, baik lisan maupun tulisan, e) kesenian sebagai mediumnya seperti seni lukis, seni rupa, seni tari, seni drama dan sebagainya, khususnya seni sastra, f) sistem pengetahuan, dan g) sistem religi.

Secara langsung atau tidak langsung, seorang penulis yang hidup di kubangan budaya masyarakat dimana ia tinggal pasti akan merefleksikan budaya masyarakatnya ke dalam karya-karya sastranya. Adakalanya, penulis tersebut hanya menulis budaya masyarakatnya an sich, namun banyak pula yang mencoba bernegoisasi, beradaptasi ataupun melawan tradisi di sekitarnya. Oleh karena itu, karya sastra tidak akan terlepas dari konteks kebudayaan masyarakat dimana penulisnya hidup.

Karena keberadaaan data antropologis tidak dapat dipungkiri pasti menjadi bagian yang terdapat di dalam karya sastra. Aspekaspek budaya yang seringkali diangkat adalah seperti sistem nilai pengetahuan, adat istiadat, sistem kekerabatan, sistem peralatan hidup dan teknologi, mata pencaharian, kesenian, serta sistem kepercayaan, dan agama (Sudikan, 2007: 6).

Maka, antropologi sastra adalah upaya untuk mendedah budaya suatu kelompok masyarakat di dalam teks-teks sastra pada sebuah kurun waktu tertentu. Nyoman Kuta Ratna (2011: 154) menyatakan bahwa antropologi sastra memiliki tugas penting untuk mengungkapkan aspek-aspek kebudayaan yang hidup masyarakat tertentu. Ia menambahkan bahwa antropologi sastra membicarakan manusia dan kebudayaan, maka semua genre, baik sastra lama maupun modern juga karya-karya yang dikategorikan sebagai postmodern, dapat dianalisis melalui antropologi sastra (2011: 248).

Dalam praktiknya, Suwardi Endraswara (2003:107) mengungkapkan bahwa penelitian antropologi sastra dapat menitikberatkan kepada dua hal. Pertama meneliti tulisan-tulisan etnografi yang berbau sastra untuk melihat estetikanya. Kedua meneliti karya sastra dari sisi pandang etnografi, yaitu untuk melihat aspek-aspek budaya masyarakat.

Sementara itu, Nyoman Kutha Ratna (2011: 248) juga menambahkan bahwa analisis antropologi sastra pada umumnya dilakukan melalui dua cara, yaitu, pertama, mendeskripsikan terlebih dahulu unsurunsur kebudayaan kemudian dilanjutkan dengan analisis secara antropologis, dan kedua, secara langsung mendeskripsikan 
melalui analisis antropologi sastra sesuai dengan tujuan penelitian. Dalam perkembangan selanjutnya yang dianggap lebih baik adalah cara yang kedua

Menurut Endraswara (2013, 61-61), antropologi sastra semestinya akan mengungkap berbagai hal, antara lain sebagai berikut. Pertama, kebiasaankebiasaan masa lampau yang berulang-ulang masih dilakukan dalam sebuah cipta sastra. Kebiasaan leluhur melakukan semedi, melantunkan pantun, mengucapkan mantramantra, dan sejenisnya menjadi fokus penelitian. Kedua, peneliti akan mengungkap akar tradisi atau subkultur serta kepercayaan seorang penulis yang terpantul dalam karya sastra. Ketiga, penelitian juga dapat diarahkan pada aspek penikmat sastra etnografis. Keempat, peneliti juga perlu memperhatikan bagaimana proses pewarisan sastra tradisional dari waktu ke waktu. Kelima, penelitian diarahkan pada unsur-unsur etnografis atau budaya masyarakat yang mengitari karya sastra tersebut. Keenam, perlu dilakukan penelitian terhadap simbol-simbol mitologi dan pola pikir masyarakat pengagumnya.

Maka, berangkat dari kerangkat tersebut di atas, penulis akan menganalisis karya-karya Djamil Suherman dengan menggunakan pendekatan antropologi sastra.

\section{METODE}

Sebagai penelitian antropologi, maka kajian penelitian ini difokuskan pada unsur-unsur etnografis atau budaya masyarakat, pola pikir masyarakat, tradisi pewarisan kebudayaan dari waktu ke waktu dan masih dilakukan.

Penelitian ini juga menggunakan metode Creswell $(2007$; 2009) tentang studi deskriptif-kualitatif yang menyajikan hasil analisis yang berupa deskripsi dan narasi. Karena penelitian deskriptif-kualitatif adalah sebagai penelitian interpretatif yang lebih berfokus pada penciptaan makna (production of meanings) (Stake 1994:242).
Maka, hasil temuan penelitian ini akan dijelaskan melalui deskripsi dan narasi.

Data dalam penelitian ini sejalan dengan studi sastra adalah berupa kata, frasa, kalimat dan simbol yang relevan dengan tujuan penelitian (Neuman, 2007: 328). Sumber data yang digunakan adalah berupa teks sastra karya Djamil Suherman yang banyak mengangkat kehidupan dan subkultur pesantren; yaitu kumpulan cerpennya Umi Kalsum (1984), novel Pejuang-Pejuang Kali Pepe (1984), novel Sakerah (1985) dan novel Sarip Tambak Oso (1985).

\section{PEMBAHASAN}

Corak-corak antropologi sastra yang dibahas dalam karya-karya Djamil Suherman dapat berupa ritual tradisi keagamaan, alat-alat budaya, elemen subkultur dan pandangan dunia. Yang pertama berupa ritual tradisi keagamaan yang menjadi cerminan budaya masyarakat pesantren. Diantaranya adalah Marhabanan, Mauludan dan Rebu Wekasan.

\section{Marhabanan}

Marhabanan berasal dari kata bahasa arab "marhaban" yang berarti selamat datang. Orang-orang Jawa Timur menyebutnya sebagai marhabanan karena ritual ini banyak mendendangkan kata "marhaban". Marhabanan sebagai ritual adalah pembacaan syair-syair pujian kepada Nabi Muhammad yang termaktub dalam kitab AlBarzanji. Di beberapa daerah atau desa, ritual ini tidak disebut sebagai Marhabanan akan tetapi Barzanjian; dari nama pengarang kitabnya; Imam Al-Barzanji. Syair-syair pujian tersebut dinyanyikan dengan lagu yang berbeda-beda dengan duduk bersila juga sesekali berdiri. Kegiatan ini dilakukan secara bergilir di masjid-masjid desa atau rumah-rumah warga selama seminggu sekali, dua minggu sekali atau bahkan sebulan sekali. Djamil Suherman mendeskripsikan dan menarasikannya sebagai berikut. 
"Ada kebiasaan lain di pesantren, di samping pengajian-pengajian umum kerap juga diadakan Marhabanan dan Kasidahan. Ini boleh dilakukan sembarang waktu di samping malam Jumat. Dan boleh dilakukan di surau atau di rumah-rumah orang yang punya hajat menghormati Nabi Muhammad, suatu upacara pujipujian kepada Nabi yang dilakukan beramai-ramai sambil duduk dan berdiri. Kadang disertai rebana." (Umi Kalsum, hal. 14)

\section{Mauludan}

Ritual ini biasanya dilakukan untuk memperingati hari lahir Nabi Muhammad yaitu pada malam ke 12 bulan robi'ul awal di kalender hijriah. Peringatan hari lahir rasul ini adalah hari kebahagiaan bagi seluruh umat islam. Di daerah pedesaan dengan kultur santri yang kuat, berbagai macam kegiatan diadakan dengan menggelar berbagai lomba seperti azan, baca al-qur'an, hafalan surat-surat pendek dan pawai busana muslim sebagai bentuk penghormatan kepada nabi yang telah membawa agama islam. Djamil Suherman menggambarkan geliat peringatan mauludan ini:

\footnotetext{
"Malam mauludan akan memberi kesempatan kepada kanak-kanak dan orang-orang yang akan memeriahkan hari besar itu, dengan arak-arakan macam karnaval. Mereka memakai topeng-topengan dan kumis palsu atau pakaian koboi yang dilengkapu dengan pistol. Ada pula yang memakai kopiah haji dengan sorban dan jubahnya. Serombongan anak-anak yang berpakaian seragam bajak laut berbaris sepanjang kampung dengan membawa pedang dan klewang kayu." (Umi Kalsum, hal. 45)
}

Rangkaian kegiatan mauludan biasanya diakhiri dengan pengajian umum yang mendatangkan seorang kiai yang memberikan ceramah agama. Isi ceramah kebanyakan tentang cerita-cerita sejarah yang berkaitan dengan kehidupan Nabi Muhammad dan anjuran untuk banyak berselawat untuk mengharap syafaat Nabi di akhirat kelak. Setelah ceramah, tumpengtumpeng makanan yang sudah dibawa dari rumah ke masjid akan dimakan bersamasama. Djamil Suherman mencatat:

"Tak lama kemudian Kyai Sjafii
mengakhiri pembacaan tarikh dengan
doa dan salawatr kepada
Nabi...Kemudian kyair kami
mengangkat kedua tangan, berdoa
diikuti oleh semua yang hadir,
mengamini. Lalu cepat, sesudah
tangan-tangan itu turun, beberapa
orang yang sudah biasa kerja
membagi-bagi tumpeng maju, dengan
mengingsutkan duduknya ke muka.
Membuka-buka daun penutup lalu
menderetkan tumpeng-tumpeng itu
sepanjang lantai surau. Kemudian
daun-daun disobek-sobek dan
diletakkan baris satu persatu di muka
masing-masing yang hadir...Tak lama
kemudia mereka mulai mencawiki nasi
dan menyobek-nyobekayampanggang
dengan kedua tangan." (Umi Kalsum,
hal 51)

\section{Rebu Wekasan}

Rebu Wekasan adalah hari rabu terakhir di bulan Safar. Dalam tradisi masyarakt Jawa, hari ini dipercaya membawa kesialan dan keburukan. Oleh karena itu, diperlukan beberapa ritual khusus untuk menolak kesialan ini. Ritualnya bisa bermacammacam seperti menunaikan salat khusus, tradisi petik laut, tumpengan di jalan raya dan lain-lainnya. Djamil Suherman juga menggarisbawahi tradisi ini dengan menguraikan kegiatan ritual dan alasan ritual itu diadakan.

"di pesantren kami, kalaupun
dipandang perlu, membersihkan
kolam biasanya dilakukan pada hari
yang disebut "Rebu-wekasan” ialah
hari Rabu, penghabisan bulan
Sya'ban. Karena menurut
kepercayaan, di hari itu Allah
berkenan menurunkan bala' besar di

"di pesantren kami, kalaupun dipandang perlu, membersihkan kolam biasanya dilakukan pada hari yang disebut "Rebu-wekasan" ialah hari Rabu, penghabisan bulan Sya'ban. Karena menurut berkenan menurunkan bala' besar di 
dunia ini selama tujuh hari tujuh malam." (Umi Kalsum, hal. 27)

Selain ritual-ritual keagamaan, corak antropologis juga dapat diamati dari bendabenda budaya sekaligus konteks bagaimana sebuah benda itu dipakai dan difungsikan dalam kurun waktu tertentu. Salah satu benda yang tertulis dalam deskripsi Djamil Suherman adalah bedug dan gambus.

Bedug dalam amatan Suherman memiliki peran penting dalam memberikan tanda dan sinyal kegiatan keagamaan. Bedug selalu tertabuh setiap hendak salat akan ditunaikan. Sebelum pengeras suara dan toa menjadi alat untuk melantangkan seruan, bedug menjadi pilihan utama untuk memanggil masyarakat dalam tanda-tanda keagamaan. Djamil melukiskan bedug dalam kaitan dengan bulan ramadan seperti ini.

\begin{abstract}
"Biasanya bunyi bedug panjang itu ditabuh orang pada permulaan bulan puasa untuk memberi tanda bahwa bulan suci sudah tiba. Atau dilakukan pada tengah malam, sebagai tanda membangunkan mereka yang hendak melakukan doa dan sahur. Atau pula dilakukan orang lepas sembahyang tarwih dengan irama tersendiri, saat kami para santri dengan sarung dan baju bersih serta kopiah lurus tunduk khusu' bertadarus semalam-malaman di surau."(Umi Kalsum, hal. 8)
\end{abstract}

Dalam gambaran Djamil Suherman, gambus sangat digemari oleh masyarakat pesantren. Jenis musik dengan alat-alat seperti gambus, mandolin, rebana, sepasang tempurung - pengocak dan sepasang bambu ketiplak ini telah mendarah daging dalam selera estetik mereka. Anak-anak muda sering mendengarkan lagu-lagu berbahasa Arab yang juga berirama Arab ini seperti "Ya Dunya Ya Gharami", "Yunadi" dan "Alfi lailah wa lailah". Syekh Ali Albar dari Surabaya juga menjadi idola untuk didengarkan dari radio. Barangsiapa yang mampu menyanyikan lagu-lagu itu dengan cengkok dan irama yang pas ia akan menjadi pusat pujian dan selalu dinantikan kehadirannya dalam acara-acara gambusan. Yang kedua, pesantren sebagai gugusan kebudayaan memiliki ciri-ciri khusus yang tidak dimiliki oleh lembaga pendidikan dan keagamaan lain. Keunikan pesantren ini ditulis oleh Zamakhsyari Dhofier (2011: 79) dalam riset antropologi sosialnya. Ia menyatakan bahwa secara umum pesantren memiliki lima elemen pokok; pondok, masjid, pengajaran kitab islam klasik, kiai dan santri. Kelima hal ini dikelilingi dan diselubungi dengan tata nilai tersendiri yang masyarakat pesantren anut.

Pertama, pondok/asrama yang menjadi tempat tinggal dan mukim santri, biasanya terletak di dalam komplek pesantren dimana kiai tinggal dan terdapat sebuah masjid. Kedekatan dengan rumah kiai dimaksudkan agar kehidupan santri dapat diamati oleh kiainya. Di pondokan inilah seorang santri biasanya menghabiskan masa mudanya selama bertahun-tahun untuk mendalami ilmu agama.

"Di belakang surau itu terletak rumah
ahli Kyai Sjafii dan di sampingnya
berderet panjang bangunan berpetak-
petak, pondok santri-santri yang
datang dari jauh, yang ingin
mengangsu ilmu bertahun-tahun di
pondok itu." (Umi Kalsum, hal. 9)
"Tak jauh dari masjid arah belakang,
berdiri beberapa petak bangunan yang
merupakan pondokan beratus-ratus
santri." (Perjuang-Pejuang Kali Pepe,
hal. 8)

Kedua, masjid; adalah sentral kegiatan di pesantren yang tidak hanya untuk tempat beribadah salat tetapi juga tempat belajar kitab kuning, dan kegiatan keagamaan lainnya seperti Marhabanan dan Kasidahan. Bahkan, masjid dipakai sebagai tempat bermusyawarah dan menentukan strategi dalam menghadapi Belanda.

Malam itu seluruh
berkumpul dalam
sebagian masjid. 
bertahan ikut hadir. Ruangan masjid Syuhada itu penuh sesak. Barangkali tak seorang pun ketinggalan. Musyawarah besar akan dilangsungkan... diungkapkannya segala masalah kehidupan pesantren, sejarah dan latar belakang Gubernemen yang hendak mencaplok hak anak pribumi. (Pejuang-Pejuang Kali Pepe, hal. 51-52)

Ketiga, pengajaran kitab islam klasik (kitab kuning) merupakan pembelajaran khas di pesantren yang mencakup banyak aspek ilmu agama seperti gramatika arab, tauhid, fiqih, hadits, ulumul qur'an, tasawuf, akhlak dan sebagainya.

Pengajaran kitab di pesantren terkenal dengan penggunaan pegon; sistem penulisan yang menggunakan aksara Arab (huruf hijaiyah) yang dimodifikisi. Aksara pegon adalah penyangga tradisi literasi di pesantren. Ia dipakai untuk mengajarkan dan memahami khazanah kitab klasik di pesantren. Kitab-kitab klasik, Djamil mencontohkan, adalah seperti Mamba'ul Ulum, Ihya Ulumuddin, Arkanul Islam, Safinah, Sullam atau Munjiyyat. Djamil Suherman dalam Umi Kalsum mengibaratkan tulisan pegon sebagai jenggot karena ditulis berentetan di bawah teks kitab asli.

Abdullah meneruskan pengajiannya dengan sebuah kitab jenggot, salah satu kitab fiqh tingkat rendah berbahasa Arab, yang bawahnya direnteti tulisan pego bahasa Jawa. Nglewer kecil-kecil seperti jenggot." (Umi Kalsum, hal. 53)

Walaupun menggunakan aksara arab, pegon lazimnya dituliskan dengan bahasabahasa lokal seperti Jawa, Madura ataupun Sunda. Aksara ini menjadi salah alat tranmisi pengetahuan dan pusat literasi sebelum aksara latin diajarkan di sekolahsekolah. Djamil mencatat dalam kumcer Umi Kalsum. “...di rumahnya Abdullah kecil membaca:

Alhamdu, utawi skehe puji, iku

Lillahi, keduwe Allah

Rabil 'alamina, kang mengerani wong alam kabeh." (Umi Kalsum, hal. 54)

Kitab kuning yang berisikan ajaranajaran keislaman seperti tauhid, tafsir, hadits, gramatika arab, akhlak dan tasawuf adalah pegangan utama para santri untuk mengenal agama mereka. Walhasil, pengajaran kitab kuning di pondok pesantren membentuk cara pandang dan sistem pengetahuan tertentu di pondok pesantren. Orang yang cerdas dan mulia di mata orangorang pesantren adalah orang-orang yang mahir dalam pengajian dan penguasaan kitab kuning. Djamil menulis "di kampung dan pesantren Gedangan jejaka atau gadis yang pintar mengaji dinilai lebih tinggi" (Umi Kalsum, hal. 25)

Keempat, kiai; merupakan pimpinan pesantren yang ahli agama islam dan mengajar kitab-kitab islam klasik. Kiai tinggal di komplek pesantren dan biasanya terletak di samping masjid. Dalam citra Djamil Suherman, kiai adalah sosok manusia yang memiliki banyak peran sosial. Kiai digambarkan sebagai sosok yang mengajar santrinya, memimpin salat berjamaah di masjid, memimpin berdoa dalam kegiatan kemasyarakatan, bahkan pemimpin perang melawan Belanda disamping secara individu adalah orang yang gemar beribadah.

"beliau suka sekali berpuasa dan siang malam melakukan sembahyang sunat" (Umi Kalsum, hal. 25)

Selain itu, Kiai di cerita-cerita Djamil Suherman selalu mewarisi darah perlawanan yang kental terhadap segala penindasan penjajahan. Mereka adalah para panglima perang. Karena itu mereka memiliki kemampuan sebagai pendekar dan pengajar silat. 
"beliau (Kiai Sjafi'i) juga punya kesaktian...memang diwarisi turun temurun dari leluhur beliau...bahwa semasa kanak-kanak beliau pernah ikut perang sabil melawan Belanda di samping ayahnya di desa Gedangan... Kyai Ahmadlah salah seorang pahlawan dan pemimpin dalam peperangan Gedangan dulu." (Umi Kalsum, hal. 25)

Kiai juga dianggap mampu untuk menyelesaikan segala masalah. Mulai dari masalah-masalah dunia seperti ekonomi, pertanian, hubungan rumah tangga, hubungan orang tua dan anak hingga masalah-masalah yang berhubungan dengan hal-hal gaib. Kiai adalah sosok yang diandalkan jika terjadi permasalahan berkaitan dengan dunia yang tak terlihat ini. Dengan doa-doa dan mantra-mantra yang ia ucapkan, para penanggung masalah berharap bahwa kiai akan meringankan beban mereka.

"Fatimah! Fatimah-dan lebih heran
lagi ketika Kyai Sjafii datang
melihatnya, seketika itu juga ia
terdiam seperti kena sihir. Beliau
meletakkan kedua tangan beliau ke
ubun-ubun kemudian pada perut dan
dadanya. Selesai itu, beliau berkenan
memanjatkan doa dan semua yang
menyaksikan sama khidmat
melihatnya. Sejak itu, Amran tak
bergerak-gerak lagi. Betapa bangga
dan takjub kami melihat kesaktian
Kyai itu." (Umi Kulsum, hal. 32)

Kelima, santri yaitu sebutan untuk murid yang belajar di pesantren. Para santri biasanya datang dari kota-kota yang jauh namun adapula yang berasal dari desa setempat. Mereka datang ke pesantren untuk belajar agama dan, pada zaman dahulu, mereka belajar selama bertahun-tahun untuk menekuni kitab-kitab.

"Mereka adalah manusia-manusia muda yang datang dengan satu tujuan, yaitu menimba ilmu akhirat dan mengamalkannya kelak bila mereka lulus dan kembali ke kampung masingmasing." (Pejuang-Pejuang Kali Pepe, hal. 8)

Selain belajar agama dan akhlak, santri juga belajar tentang hidup dan kemandirian. Maka, sejak usia muda santri harus dapat berdiri sendiri dalam segala hal. Djamil menyebut kemandirian santri dalam hal memasak, mencuci, setrika baju dan menimba air. Di sisi lain, mereka juga belajar tentang ketrampilan-ketrampilan hidup lainnya.

Mereka selain dididik sebagai orang-
orang takwa dan taat beribadah
dengan menimba ilmu agama
sebanyak-banyaknya, juga mereka
diajar ketrampilan. Mereka mendapat
pelajaran praktek bertukang, bertani,
kerajinan tangan serta keterampilan-
keterampilan lainnya. "(Pejuang-
Pejuang Kali Pepe, hal. 32)

Selain kitab kuning dan kemandirian, salah satu ketrampilan yang harus dipelajari seorang santri adalah pencak silat. Untuk menguasainya tidak hanya latihan fisik yang harus dilakukan tetapi juga tirakat ibadah batin sebagai benteng pertahanannya. Djamil menggambarkan bahwa seorang santri yang ingin memperdalam silat, ia harus berpuasa selama 40 hari plus puasa "mutih" selama tujuh hari tujuh malam. Puasa "mutih" artinya puasa dimana waktu berbuka dan sahur si pelaksana hanya diperbolehkan makan dengan yang putihputih semata, seperti nasi dan air putih. Selain itu mereka juga harus menunaikan salat hajat setiap tengah malam dan merapal mantera-mantera. Ritual ini adalah sebagai bentuk penempaan diri bagi seorang pesilat.

Yang ketiga adalah bahwa pesantren juga mendidik masyarakatnya untuk menganut sebuah pandangan hidup tertentu. Pandangan hidup yang disarikan dari ajaranajaran agama. Melalui pendirian tokohtokohnya, Djamil menjelaskan tentang nilainilai yang terpatri dalam pikiran orang-orang 
yang tinggal di pesantren. Salah satu nilai tersebut adalah kepedulian sosial. Tokoh Sakerah digambarkan sebagai seorang jagoan yang mahir dalam dunia persilatan. Masa mudanya penuh dengan kejayaan yang berhasil mengalahkan semua musuh-musuh yang menentangnya. Ia begitu jumawa dan tak terkalahkan. Namun, semuanya berubah saat ia berinteraksi dan bertemu dengan kiai. Kedekatannya dengan seorang kiai membuatnya merubah haluan pikirannya. Ia lalu mempergunakan keahlian dan silatnya untuk membantu orang-orang lemah dan tertindas, yaitu orang yang ditindas oleh kolonialisme Belanda pada waktu itu.

\begin{abstract}
"Sakerah memandang bahwa yang terpenting dalam hidup ini adalah kebaikan. Kebaikan pada diri sendiri, keluarga dan orang lain. Pandangan demikian timbul saat-sat dia menyadari bahwa kejagoan manusia sebenarnya tidaklah ada artinya dibandingkan dengan kekuasaan Maha Pencipta." (Sakerah, hal. 2)
\end{abstract}

Begitu juga dengan pemuda bernama Sarip di novel lain. Sebagai seorang santri dengan penuh kesaktian, ia membaktikan dirinya kepada kiai. Perannya semakin jelas saat Belanda dan antek-antek pribuminya mulai mengganggu kehidupan di desa Tambak Oso. Kegaduhan dan keributan sosial sengaja dibuat. Sarip lah yang kemudian berdiri paling depan dan orang yang pertama-tama melawan melihat ketidakadilan sosial yang melanda masyarakat di sekitar pesantren.

"Kita punya tugas sosial di desa ini, Kang. Aku tidak bisa menyaksikan ketidakadilan hidup ini, aku ingin menyumbangkan sesuatu kepada masyarakat, kepada orang Tambakoso yang menderita ini. Aku ingin membebaskan mereka." (Sarip Tambak Oso, hal. 51)

Nilai pandangan hidup yang juga sangat menonjol dalam karya Djamil Suherman adalah terhadap kolonialisme. Pesantren menjadi tempat persemaian kecintaan terhadap tanah air. Kalimat hubbul wathon minal iman berdegup di dada para santri. Saat Belanda menjajah bangsa ini, santri adalah salah satu laskar yang dengan gigih bertempur melawan karena mereka meyakini bahwa agama dan kebangsaan dalam satu tarikan nafas yang sama. Kiai dan santri beserta masyarakat di sekitar pesantren bahu membahu untuk mengusir penjajah dari desanya. Seperti yang dikatakan Ismail, tokoh santri dalam novel Djamil Suherman.

“..Demikianlah saudara-saudara,
pesantren dan desa kita terancam
bahaya dan kita tak mungkin
mengelakkannya. Denganancaman itu
maka perasaan agama kita
tersinggung. Juga perasaan
kebangsaan, sebagai bangsa yang
berhak mewarisi bumi ini.” (Pejuang-
Pejuang Kali Pepe, hal. 52)

Kiai digambarkan sebagai orang yang mengerti agama menjadi pionir dalam perlawanan terhadap Belanda. Kiai-kiai dalam cerita Djamil adalah kiai desa yang menyusun kekuatan dengan mengerahkan para santri dan penduduk desa untuk bersama-sama menyatukan niat untuk membebaskan desa mereka. Mereka juga penyusun strategi dan penentu langkah dalam menyelematkan desa dari pendudukan kompeni. Kiai berada pada barisan terdepan untuk menghalau kehadiran para penjajah.

"Allahu Akbar!" teriak Kiyahi
Mukmin. Dengan kerisnya Kiyahi
Mukmin mengamukyang dalam waktu
singkat telah berhasil menewaskan
duabelas serdadu komepni, termasuk
seorang Komandan Belanda yang
menerobos masuk pesantren. Kiyahi
yang wajahnya telah berubah jantan
perkasa dengan garangnya menerjang
serdadu-serdadu kompeni yang telah
bertebaran di halaman masjid.
"(Pejuang-pejuang Kali Pepe, hal.
112)




\section{SIMPULAN}

Paparan di atas menunjukkan bahwa karyakarya Djamil Suherman adalah sebagai catatan antropologi sosial yang penting tentang subkultur pesantren. Novel dan cerita pendeknya penuh dengan narasi dan deskripsi ritual keagamaan pesantren, elemen-elemen pesantren dan pandangan hidup orang-orang pesantren.

Ia mendeskripsikan ritual tradisi keagamaan yang berlangsung di masyarakat pesantren yang mungkin sudah semakin berkurang di zaman sekarang. Ia juga mengitari dan

\section{DAFTAR PUSTAKA}

Creswell, JW. (2007). Qualitative Inquiry and Research Desain. London: Sage, 2007. Creswell, JW. (2009). Research Design, Qualitatif, Quantitative, and Mixing Approaches. London: Sage.

Dhofier, Zamakhsari. (2011). Tradisi Pesantren; Studi Pandangan Kyai dan Visinya Mengenai Masa Depan Indonesia. Jakarta: LP3ES.

Endraswara, Suwardi. (2013). Metodologi Penelitian Sastra. Epistemologi, Model, Teori, dan Aplikasi. Yogyakarya: Pustaka Widyatama.

Endraswara, Suwardi. (2013) Metodologi Penelitian Antropologi Sastra. Yogyakarta: Penerbit Ombak.

Jassin, H.B. (1961) "Ulasan”, Analisa. Jakarta: Gunung Agung.

Koentjaraningrat. (1974). Pengantar Antropologi. Jakarta: Aksara Baru.

Mihardja, Achdiat K. (1986). Polemik Kebudayaan. Jakarta: Penerbit Pustaka Jaya.

Neuman WL. (2007) Basics of Social Research: Qualitative and menarasikan elemen-elemen pesantren dengan nilai dan norma yang sedang berlaku di masa itu. Pandangan hidup orang-orang pesantren ia rekam dengan baik dalam karya-karya sastranya.

Di tengah gelombang modernisasi dan perubahan pesantren, membaca kembali karya-karya Djamil Suherman adalah upaya untuk kembali menjaga tata nilai-nilai dan norma-norma kebudayaan masyarakat pesantren. Karena kebudayaan masyarakat pesantren juga terefleksikan dalam karya sastra, termasuk karangan Djamil Suherman.

Quantitative Approaches. Boston: Pearson.

Rakhmat, Jalaludin. (1984) "Pesantren: Subkultur yang Hampir Punah", Pejuang-Pejuang Kali Pepe. Bandung: Penerbit Pustaka.

Ratna, I Nyoman Kuta. "Antropologi Sastra; Perkenalan Awal", Metasastra, Vol. 4 No. 2 Desember 2011. hal. 150-159.

Ratna, Nyoman Kutha. (2011). Antropologi Sastra; Peranan Unsur-Unsur Kebudayaan dalam Proses Kreatif. Yogyakarta: Pustaka Pelajar.

Ratna, Nyoman Kutha, “Antropologi Sastra; Mata Rantai Terakhir Analisis Ekstrinsik", Mabasan, Vol. 5, N0.1, Januari-Juni 2011, pp 39-50

Stake, RE. (1994). Case Studies. In: NK Denzin \& YS Lincoln (Eds.) Handbook of Qualitative Research, London: Sage Publications, pp. 236-247.

Sudikan, Setya Yuwana. (2007). Antropologi sastra. Surabaya: Unesa University Press.

Suherman, Djamil. (1984). Umi Kulsum; Kisah-Kisah Pesantren. Bandung: Mizan.

Suherman, Djamil. (1985). Sakerah. Bandung: Penerbit Pustaka. 
Waro’i: Subkultur Pesantren ....

Suherman, Djamil. (1985). Sarip Tambak Oso; Kisah-Kisah Seorang Ibu. Bandung: Penerbit Mizan.

Suherman, Djamil. (1984). PejuangPejuang Kali Pepe. Bandung: Penerbit Pustaka.

Wahid, Abdurrahman. (1974)."Pesantren sebagai Subkultur", Pesantren dan Pembaharuan, M. Dawam Rahardjo (ed.), Jakarta: LP3ES.
Wahid, Abdurrahman. (2010) "Pendidikan Tradisional di Pesantren", Menggerakkan Tradisi; Esai-Esai Pesantren, Yogyakarta: LkiS.

http://pbsb.ditpdpontren.

Kemenag.go.id//pdpp/ diakses pada 12 Juni 2019 